\title{
Litteratur
}

Engeström, Yrjö, 1987: Learning by expanding: An activity-theoretical approach to developmental research. Helsingfors: Orienta-konsultit.

Engeström, Yrjö, 2001. Expansive Learning at Work: Toward an activity theoretical reconceptualization. I: Journal of Education and Work 14(1). S. 133-156.

Gunnarsson, Britt-Louise, Linell, Per \& Nordberg, Bengt, 2016: The Construction of Professional Discourse. London: Routledge.

Lassus, Jannika, 2010: Betydelser i barnfamiljsbroschyrer. Systemisk-funktionell analys av den tänkta läsaren och institutionen. Helsingfors: Helsingfors universitet.

Lind Palicki, Lena, 2010: Normaliserande föräldrar. En undersökning av Försäkringskassans broschyrer 1974-2007. Örebro universitet.

Nordman, Lieselott, 2009: Lagöversättning som process och produkt. Revideringar och institutioner vid lagöversättning till svenska i Finland. Nordica Helsingiensia 16. Helsingfors: Helsingfors universitet.

Nyström Höög, Catharina, Söderlundh, Hedda \& Sörlin, Marie, 2012: Myndigheterna har ordet. Om kommunikation i skrift. (Språkrådets skrifter 14.) Stockholm: Norstedts.

Ohlson, Claes, 2007: Folkets fonder? En textvetenskaplig studie av det svenska pensionssparandets domesticering. Göteborg: Institutionen för svenska språket.

Toury, Gideon, 1995: Descriptive Translation Studies and Beyond. Amsterdam: Benjamins.

Lieselott Nordman

Gustafsson, Anna W. \& Håkansson, David: Ord på prov. En studie av ordförståelse i högskoleprovet. (Lundastudier i nordisk språkvetenskap A 75.) $144 \mathrm{~s}$. Lunds universitet 2017. ISSN 0347-8971, ISBN 978-91-88473-7 (tryck), 978-91-88473-43-1 (pdf).

I Ord på prov. En studie av ordförståelse i högskoleprovet redovisar och diskuterar Anna W. Gustafsson och David Håkansson en omfattande studie av ordförståelse i dagens samhälle. I inledningen ger de en bakgrund till sin forskning om ordförståelse; det finns flera anledningar till att det är ett både viktigt och intressant område att undersöka. Bland annat har de sjunkande resultaten i PISA-rapporterna mellan 2000 och 2012 vad gäller läsning lett till mycket debatt, men läsning och ordförståelse har diskuterats sedan mycket längre tillbaka, och redan på 1970-talet genomfördes studier som lyfte frågan om samhälleliga klyftor beträffande ordförståelse hos vuxna. I den här studien anknyter författarna till det demokratiska perspektivet i 70-talets undersökningar.

Det övergripande syftet är att studera förändring i ordförståelse över tid, och materialet består av cirka 900000 svar från ordförståelsedelen i högskoleprovet mellan åren 2000 och 2011. Högskoleprovet startade 1977, men ordförståelseprovet har förändrats en del sedan dess. Under perioden 2000-2011 var emellertid förutsättningarna för 
ORD-provet »relativt konstanta» (s. 17) med 40 uppgifter, och utprövningarna av uppgifterna gick till på samma sätt. Högskoleprovet ska fungera som ett urvalsinstrument till högre utbildning och spegla kunskapsnivån i samhället, och därför är de enskilda proven inte direkt jämförbara med varandra. Däremot kan resultaten över tid jämföras genom att man ställer olika grupper i relation till varandra. Den första delstudien i undersökningen utgår från frågeställningen: »Hur har resultaten på ORD-provet förändrats över tid när olika grupper ställs i relation till varandra?»

Den andra delstudien utgår från frågeställningen: »Hur har förståelsen av individuella ord och begrepp utvecklats över tid?» Man kan inte säga något om förståelsen av enskilda ord genom att jämföra de olika gruppernas provresultat, men eftersom alla ord som finns med i högskoleprovet tidigare har testats på en mindre grupp deltagare kan resultaten från utprövningarna i den mindre gruppen jämföras med resultaten från de reguljära ORD-proven.

I kapitel 2 beskrivs några utgångspunkter för studien, nämligen vad det innebär att förstå ett ord och hur ordförståelse kan relateras till läsförståelse, hur ordförståelse kan testas, några tidigare studier av ordförståelse och ordförråd samt några aktuella studier av svenskars läs- och medievanor. Bland annat återges en intressant diskussion om kritik som tidigare riktats mot flervalstester av enskilda ord utan kontext. Jag har själv många gånger funderat på vad den här typen av test utan kontext visar och på hur viktigt men svårt det är att välja bra distraktorer, dvs. de olika alternativ som ges till det rätta svaret. Gustafsson och Håkansson ger en tydlig bild av fördelar och nackdelar med olika typer av test. De framhåller att det också finns argument för ordförståelseprov av flervalstyp, t.ex. att resultaten korrelerar med test av problemlösningsförmåga, och de drar slutsatsen att ordförståelseprov av flervalstyp »kanske har sitt berättigande i ett högskoleprov som ska fungera som urvalsprov och mäta studieförmågan (i vilken problemlösningsförmåga torde vara en viktig komponent)» (s. 22). Författarna är överhuvudtaget försiktiga med att uttrycka att något är på det ena eller det andra sättet. De är mycket nyanserade också när de diskuterar sina resultat, vilket jag återkommer till.

Läsförståelse och ordförståelse hänger nära samman, och i avsnittet om studier som gjorts av läsning och medievanor redovisas resultat från Nordicoms årliga undersökning av hur svenskars medievanor ser ut. Konsumtionen av traditionella medier minskade mellan 1997 och 2014, medan användningen av internet ökade. Däremot är andelen läsare av skönlitteratur relativt konstant under hela perioden. Det är framför allt den yngsta åldersgruppen, 15-24 år, som har ökat sin mediekonsumtion via internet och samtidigt kraftigt minskat tidningsläsandet. Gustafsson och Håkansson refererar också till en studie från 2013 som visar att läsförståelsen påverkas negativt av skärmläsning. De uttrycker slutligen i kapitel 2 att det inte förefaller orimligt att minskningen i läsning av olika traditionella medier har haft betydelse för ordförståelsen.

I kapitel 3 ges en gedigen beskrivning av olika aspekter av högskoleprovet, framför allt syftet med provet och principerna för konstruktionen. Fokus ligger på hur ordförståelseprovet konstrueras och vilken typ av ord som prövas.

I kapitel 4 besvaras frågan i den första delstudien om hur resultaten på ORD-provet har förändrats över tid. Det övergripande resultatet är att poängmedelvärdet för samtliga provdeltagare sjönk från 21,76 poäng våren 2000 till 19,86 våren 2011, men som författarna tidigare diskuterat kan jämförelsen mellan de olika provtillfällena inte ge ett tillförlitligt svar om förändringar över tid. Därför undersökte de skillnaderna mellan delta- 
gare från olika åldersgrupper, med olika utbildningsbakgrund och med olika könstillhörighet samt sambandet mellan olika variabler. Vid alla provtillfällen hade de äldre åldersgrupperna (25-39 år och 40 år eller äldre) ett högre poängmedelvärde än de yngre (20 år eller yngre och 21-24 år). Den yngsta åldersgruppen är alltid den största och den äldsta åldersgruppen den minsta, och medelåldern har under undersökningsperioden sjunkit från drygt 23 år till under 22 år. Poängmedelvärdet för den yngsta åldersgruppen har sjunkit över tid, medan poängmedelvärdet för den äldsta åldersgruppen har ökat; spännvidden mellan grupperna var våren $2000 \mathrm{ca} 11$ poäng, och våren $2011 \mathrm{ca} 15$. Klyftorna började öka 2005.

Det tydligaste resultatet vad gäller provdeltagarnas utbildningsbakgrund är att spännvidden mellan de provdeltagare som har högskoleutbildning $(15,1 \%$ av alla hade genomgått svensk högskoleutbildning i någon form) och de som inte har det ökade mot slutet av undersökningsperioden. Vid alla provtillfällen som undersöktes var poängmedelvärdet högre för provdeltagare med högskoleutbildning; den minsta skillnaden var 6,6 poäng, och våren 2011 uppgick den till 10,2 poäng.

Vad gäller kön är 53,9 \% av provdeltagarna i materialet kvinnor och 46,1 \% män. Skillnaden mellan kvinnor och män är små och det finns inga tendenser till att skillnaden ökar över tid. Den var cirka en halv poäng både vid undersökningsperiodens början och slut, men 2000 var det kvinnorna som hade högre poängmedelvärde och 2011 männen. Gustafsson och Håkansson visar att skillnaderna i poängmedelvärde mellan män och kvinnor åtminstone delvis beror på samvariation mellan kön, utbildning och ålder.

De statistiska beräkningarna visar att under hela undersökningsperioden är åldersgrupp respektive högskoleutbildning de variabler som förklarar den största delen av variationen i provresultatet på ORD-provet, $15,3 \%$ respektive $12,4 \%$ vad gäller materialet i sin helhet. Kön förklarar alltid mindre än $1 \%$ av variationen.

Genom alla de beräkningar och jämförelser Gustafsson och Håkansson gör kan de visa att det minskade poängmedelvärdet över tid inte beror på att provet har blivit svårare. Metoden de använder sig av är väl genomtänkt och de utför en mycket noggrann analys där de vänder på varje sten, vilket också gäller den andra delstudien.

Den andra delstudien som handlar om hur förståelsen av enskilda ord har förändrats över tid presenteras i kapitel 5 . Valet av ord skedde efter följande principer: ord som utprövades minst tre år före reguljärprovet, uppgifter som är identiskt utformade vid båda provtillfällena, ord som förekommer med en rimligt hög frekvens i språkbruket samt bjudord som består av enstaka ord, dvs. flerordsuttryck som utan krumbukter utesluts. För att inte få med mycket lågfrekventa eller alltför specialiserade ord begränsades valet till ord som förekommer minst 100 gånger i tidningstext och skönlitteratur (Språkbanken, Göteborgs universitet: DN 1987; GP 2001-2013; Norstedtsromaner 1999). Efter alla avgränsningar återstod 151 ord, och alla presenteras i en tabell med uppgifter om provår och antal provsvar vid respektive provtillfälle.

För ungefär hälften (74) av de totalt 151 ord som ingår i undersökningen försämrades resultatet signifikant över tid när reguljärproven jämförs med utprövningarna, medan resultatet för cirka en fjärdedel av orden (36) förbättrades signifikant. De flesta ord som uppvisar signifikanta försämringar testades i slutet av undersökningsperioden. Den genomsnittliga försämringen är större än den genomsnittliga förbättringen. Förståelsen av ordet entreprenör har förbättrats mest med 18,8 procentenheter och progressiv har förbättrats med 13,3 procentenheter. Av de tio ord där förståelsen har förbättrats mest har 
de flesta en förbättring på 6-7 procentenheter. Ordet pådrag är det ord som förståelsen har försämrats mest för, med 25,7 procentenheter, och försämringen för ordet kulvert är 23,5 procentenheter. Övriga ord som ingår i kategorin där förståelsen har försämrats mest uppvisar en försämring på 13,6-17,7 procentenheter.

En noggrann utredning av hur förståelsen av ord har förändrats i de olika åldersgrupperna presenteras; för jämförelsen mellan olika åldersgrupper har de två äldsta åldersgrupperna slagits ihop till en. Försämringen i ordförståelse är tydligast i de yngsta åldersgrupperna. Vad gäller jämförelsen mellan manliga och kvinnliga provdeltagare visade sig skillnaderna genomgående vara små. Gustafsson och Håkansson jämför också provresultaten med ordens frekvens, vilka orter som orden prövades ut på samt ordens ursprung. Det finns ett visst samband mellan graden av förbättring och ordens frekvens i tidningstext och skönlitteratur.

Utprövningarna av orden sker varje gång på en mindre grupp inom en högskoleregion, och den genomsnittliga normerade poängen varierar mellan olika högskoleenheter. För att utesluta att resultaten reflekterar skillnader mellan olika provorter jämförs utprövningsresultatet med resultatet på reguljärprovet bara på den aktuella högskoleenheten. I sin analys av skillnader mellan provorter kommer Gustafsson och Håkansson fram till att resultaten egentligen är sämre än de kan verka. Huvuddelen av de ord som försämrats visar ett signifikant resultat oavsett om de jämförs utifrån samtliga provorter i reguljärprovet eller begränsas till den aktuella högskoleenheten, medan de ord som uppvisade en förbättrad förståelse ofta hade provats ut vid högskoleenheter med ett genomsnittligt sämre resultat.

Vad gäller samband mellan ordens ursprung och graden av förändring dominerar ord som har ett romanskt ursprung eller har lånats in i svenskan direkt från engelskan bland de ord som har förbättrats över tid, medan ord med nordiskt eller tyskt ursprung dominerar bland de ord som har försämrats signifikant över tid. Engelskans starka ställning i Sverige är en förklaringsfaktor till att förståelsen för engelska ord har förbättrats signifikant över tid. Engelskan har haft stor inverkan på svenskans ordförråd under flera decennier, och svenska ungdomars mediekonsumtion sker i dag ofta på engelska

I sin avslutande diskussion i kapitel 6 kommer Gustafsson och Håkansson in på förklaringar till att unga får allt svårare att förstå ord. De som gjorde provet under andra hälften av 2000-talets första decennium hör till den första generation som är uppvuxen med internet. Resultaten kan kopplas till läsvanor och erfarenheter av olika typer av texter; t.ex. har läsningen av morgontidningar minskat starkt i yngre åldrar.

Slutligen lyfter Gustafsson och Håkansson att de klyftor i ordförståelse som deras studie visar inte bara är ett språkligt utan också ett demokratiskt problem. När ordförståelsen minskar kan det bli svårare att delta i det medborgerliga samtalet. Risken är också stor att det blir svårare för fler studenter att lyckas i sina universitetsstudier.

Gustafsson och Håkansson framhåller att skolans roll är central, och de föreslår hur skolan kan arbeta: »Det förefaller inte orimligt att de ganska nedslående tendenser till försämrad ordförståelse som vi har visat på kan mötas med ett mer intensivt arbete med texter i olika genrer och i olika ämnen i skolan» (s. 132). Som tidigare nämnts är författarna alltid nyanserade i sina uttalanden, ibland på gränsen till för försiktiga. Men denna försiktighet att säga något med säkerhet leder också till att de är utomordentligt noggranna och utför alla undersökningar och jämförelser som kan tänkas vara relevanta för att öka studiens validitet. Det är också positivt att inte mötas av tvärsäkra påståenden 
som så ofta i dagens debatt om till exempel skolan och elevernas dåliga resultat. Debatten i medier och bland politiker blir ofta onyanserad där åsikter bygger mer på känslor än fakta.

Det är imponerande hur Gustafsson och Håkansson har tänkt ut metoder för sin undersökning och hur noggrant de analyserar det stora materialet. Trots ganska komplicerade undersökningar beskriver de metod och resultat på ett tydligt sätt, vilket gör att det går bra att följa deras resonemang. Jag hoppas att den här boken sprids inom skolvärlden och läses både av lärare och blivande lärare. Alla lärare bör arbeta aktivt med ordförståelse och uppmuntra till läsning av olika slags texter.

\section{Eva Sundgren}

Josefsson, Gunlög \& Lundin, Katarina: Nycklar till grammatik. 158 s. Studentlitteratur. Lund 2018. ISBN 978-91-44-11759-1.

Det senaste decenniet har ett flertal läroböcker givits ut med uttalat syfte att användas på nybörjar- och fördjupningskurser i grammatik vid svenska universitet och högskolor. Denna boks författare, Gunlög Josefsson och Katarina Lundin (båda sedan många år verksamma vid Lunds universitet), har enskilt eller i samarbete bidragit med fem tidigare läroböcker om grammatik, och får således sägas vara något av veteraner i sammanhanget. Josefssons bok Universitetsgrammatik för nybörjare har sedan 2001 använts på många olika universitets- och högskoleutbildningar i svenska, och Katarina Lundins Tala om språk (2014) har på samma sätt använts inom flera lärarutbildningar. Med tanke på just det stora antalet läroböcker i svensk grammatik måste man naturligtvis ställa sig frågan: vilket syfte, eller vilken lucka, fyller Nycklar till grammatik?

I inledningen (s. 14) beskriver författarna själva boken som »en fortsättnings- och fördjupningsbok i grammatik, med ett tydligt praktiskt anslag och en möjlighet till konkret tillämpning». Detta relativt mångfacetterade syfte reflekteras också i urvalet och dispositionen av bokens innehåll. Snarare än en traditionell genomgång av ord, fraser, satsled och satstyper utgår Nycklar till grammatik från vanliga fallgropar och svårigheter vid grammatisk analys: avgränsningen av fraser och satser, den språkliga hierarkin samt relationen mellan form, funktion och betydelse. Ett friskt grepp är att låta stora delar av diskussionen utgå från autentiska felanalyser från grammatikstuderande. Exemplen är väl valda illustrationer av vanliga feltyper (pedagogiskt markerade i rött med en tummen-ner-markör framför) och kontrasteras ofta med den korrekta analysen (markerad i grönt med en tummen-upp-markör) i direkt anslutning.

Boken inleds med ett kortare metakapitel om bokens syfte och disposition samt dess tänkta läsare. Kapitel 2 är således det första innehållskapitlet, med en genomgång av språkets byggstenar (fraser, satsförkortningar och bisatser). Kapitel 3 diskuterar språkets tre dimensioner form, funktion och betydelse - en central aspekt som brukar avhandlas i alltför korta avsnitt i många grammatikböcker. I kapitel 4 diskuteras den hierarkiska principen, också detta ett välkommet inslag. Kapitel 5 fokuserar på »Bekymret med bisatser», medan kapitel 6 behandlar satsschemat som såväl en linjär representation 